Original Research Paper

\title{
Pelatihan Penulisan Karya Ilmiah untuk Pengembangan Keprofesian Berkelanjutan Guru TK dan MI Yayasan Pondok Pesantren Darussholihin NW Kalijaga Kabupaten Lombok Timur
}

\author{
Lalu Muhaimi ${ }^{1,3}$, A Hari Witono ${ }^{1}$, Sudirman Wilian ${ }^{1,3}$, Joni Rokhmat $^{2,4}$, Najah ${ }^{1}$, Dedy Efendy ${ }^{1}$ \\ ${ }^{1}$ Department of Education Administration, Postgraduate Program, University of Mataram, Indonesia \\ ${ }^{2}$ Department of Science Education, Postgraduate Program, University of Mataram, Indonesia \\ ${ }^{3}$ Department of English Language Education, Teacher Training and Education Faculty, University of Mataram, \\ Indonesia \\ ${ }^{4}$ Department of Physics Education, Teacher Training and Education Faculty, University of Mataram, Indonesia
}

https://doi.org/10.29303/jpmpi.v3i2.1217

Sitasi: Muhaimi, L., Witono, A. H., Wiliam, S., Rokhmat, J \& Efendy, D. (2021). Pelatihan Penulisan Karya Ilmiah untuk Pengembangan Keprofesian Berkelanjutan Guru TK dan MI Yayasan Pondok Pesantren Darussholihin NW Kalijaga Kabupaten Lombok Timur. Jurnal Pengabdian Magister Pendidikan IPA, 4(4)

\begin{abstract}
Article history
Received: 15 September 2021 Revised: 20 September 2021

Accepted: 30 November 2021

*Corresponding Author: Joni Rokhmat, University of Mataram, Mataram, Indonesia; Email: joni.fkip@unram.ac.id
\end{abstract}

\section{Pendahuluan}

Pengabdian Kepada Masyarakat (PKM) termasuk salah satu unsur dari pelaksanaan Tri Dharma Perguruan Tinggi. Berdasar permenristekdikti nomor 44 tahun 2015 tentang Kerangka Kualifikasi Nasional Indonesia (KKNI) Pasal (1) ayat 12, PKM juga merupakan kegiatan

\begin{abstract}
Pengembangan keprofesian berkelanjutan menjadi satu program pengembangan kualitas guru pada umumnya, salah satunya melalui peningkatan publikasi ilmiah. Pengabdian ini bertujuan membantu guru TK dan MI Yayasan Ponpes Darussolihin NW Kalijaga Kab. Lombok Timur untuk meningkatkan kemampuannya menyusun karya ilmiah. Kegiatan dilakukan menggunakan media zoom dan diikuti oleh 45 guru yang terdiri atas 11 guru TK dan 34 guru MI. Penyampaian materi dibagi atas pemaparan pentingnya publikasi ilmiah, kerangka konseptual karya ilmiah, Penelitian Tindakan Kelas (PTK), dan diakhiri dengan kegiatan diskusi dan pengisian angket menggunakan google form. Hasilnya memperlihatkan efektivitas kegiatan pengabdian yang antara lain direpresentasikan peserta berupa ketekunan keikutsertaan kegiatan hingga akhir, kuantitas pertanyaan yang disampaikan dalam sesi diskusi, serta keseriusan peserta mengisi angket. Selain itu, peserta berharap agar kegiatan ini dilanjutkan dan dilakukan secara berkesinambungan dengan materi PTK secara lebih operasional. Direkomendasikan agar kegiatan ini dilaksanakan secara teratur dengan frekuensi sesuai dengan kebutuhan para guru.
\end{abstract}

Keywords: Pengembangan keprofesian berkelanjutan, peublikasi ilmiah, penelitian tindakan kelas, pengabdian untuk guru TK dan MI

sivitas akademika sebagai wadah implementasi untuk ilmu pengetahuan dan teknologi guna menunjang perwujudan kesejahteraan masyarakat dan upaya mencerdaskan kehidupan bangsa. Selanjutnya, pada Pasal (55) ayat (2) disebutkan bahwa hasil PKM dapat berbentuk penyelesaian masalah yang dihadapi masyarakat dengan memanfaatkan keahlian sivitas akademika yang relevan, teknologi tepat guna, bahan pengembangan ilmu pengetahuan dan teknologi, atau bahan ajar 
atau modul pelatihan untuk pengayaan sumber belajar.

Kualifikasi profesional guru dapat ditingkatkan melalui peningkatan jabatan fungsional dan kepangkatan yang dapat dilakukan dengan menyusun karya ilmiah sesuai dengan bidang keahliannya. Berdasar permendiknas nomor 35 tahun 2010, tentang petunjuk teknis pelaksanaan Jabatan Fungsional Guru dan Angka Kreditnya, jumlah angka kredit yang harus dikumpulkan seorang guru dari sub-unsur publikasi ilmiah dan/atau karya inovatif, serta jenis publikasi yang wajib ada (minimal satu publikasi) saat mengajukan kenaikan dari satu jabatan ke jabatan lain yang setingkat lebih tinggi telah diatur.

Seorang guru pada jabatan Guru Muda pada golongan IIId ketika mengusulkan kenaikan jabatan dan/atau pangkat diwajibkan mengumpulkan sub-unsur publikasi ilmiah yang merupakan karya tulis hasil laporan penelitian. Tabel itu juga memperlihatkan besaran kredit yang harus dikumpulkan untuk sub-unsur ini, apabila seorang guru mengusulkan kenaikan pangkat dari Guru Muda IIId ke Guru Madya IVa, Guru Madya IVa ke Guru Madya IVb, Guru Madya IVb ke Guru Madya IVc, Guru Madya IVc ke Guru Utama IVd, serta dari Guru Utama IVd ke Guru Utama IVe. Jumlah minimal sub-unsur ini, masing-masing 8 (delapan), 12 (dua belas), 12 (dua belas), 14 (empat belas), dan 20 (dua puluh). Sub-unsur publikasi ilmiah ini menurut tingkatan dari yang cukup diseminarkan di tingkat sekolah dan disimpan di perpustakaan hingga publikasi ilmiah yang diterbitkan/dipublikasikan dalam majalah/jurnal ilimiah tingkat nasional yang terakreditasi.

Situasi ini berimplikasi ketika seorang guru yang berada pada jabatan Guru Muda dengan golongan IIId tidak dapat mengajukan kenaikan jabatan dan/atau pangkat jika ia tidak pernah melakukan penelitian yang selanjutnya dilaporkan sebagai karya ilmiah yang sekurang-kurangnya dipublikasikan pada tingkat perpustakaan sekolah. Di sisi lain, sepengetahuan tim pengabdian, hasil studi pendahuluan pada guru-guru, termasuk guruguru TK Yayasan Pondok Pesantren Darussholihin NW Kalijaga Kabupaten Lombok Timur, pada praktik pembelajaran di kelas disadari maupun tidak dalam meningkatkan kualitas proses pembelajaran, cukup banyak guru yang selalu membuat perlakuan-perlakuan yang baru atau paling tidak membuat perlakuan berbeda dari sebelumnya yang dipandang lebih efektif dan efisien daripada pembelajaran sebelumnya. Apabila tindakan itu diadmistrasikan dan dianalisis, serta dilaporkan sebagai dokumen penelitian maka laporan itu menjadi salah satu bentuk karya ilmiah. Selanjutnya, hasil penelitian itu dapat dikembangkan sebagai karya ilmiah untuk dipublikasikan dalam bentuk tulisan jurnal ilmiah. Namun demikian, selama ini kegiatan itu tidak diorganisir menjadi sebuah penelitian dan karya ilmiah.

Para guru pada umumnya tidak memiliki karya ilmiah dan penyebabnya adalah tidak mengetahui cara menyusunnya dan situasi ini berjalan cukup lama sehingga mereka terlanjur merasa nyaman pada kondisi seperti ini. Untuk mengubahnya, kepada para guru perlu diberikan stimulus yang cukup kuat untuk menyadarkan bahwa mereka pada dasarnya mampu dan memiliki peluang untuk mengembangkan karya ilmiah baik berbasis hasil penelitian maupun kajian pustaka untuk dipublikasikan pada jurnal nasional lokal atau nasional terakreditasi, atau lebih tinggi lagi dipublikasikan pada jurnal internasional bereputasi.

Sementara itu, di beberapa sekolah, upaya pelatihan karya ilmiah juga sudah dilakukan para guru melalui kerjasama dengan sejumlah dosen di Universitas Mataram. Namun demikian, fakta menunjukkan dari sejumlah guru yang mengikuti pelatihan tersebut, sepengetahuan penulis, tidak lebih dari $10 \%$ atau bahkan tidak ada sama sekali guru yang melanjutkannya hingga tersusun karya ilmiah baik dari hasil kajian pustaka maupun dari hasil kegiatan penelitian, khususnya penelitian tingakan kelas.

Melihat situasi ini, kami para dosen di program studi Magister Administrasi Pendidikan, Universitas Mataram, merasa terpanggil untuk mengadakan kegiatan pendampingan penyusunan karya ilmiah bagi para guru pada jenjang pendidikan Taman Kanak-kanak, yaitu pada guru TK Yayasan Pondok Pesantren Darussholihin NW Kalijaga Kabupaten Lombok Timur. Kegiatan ini adalah pembekalan penyusunan atau penyempurnaan karya ilmiah sebagai hasil dari penelitian (penelitian tindakan kelas) atau hasil kajian pustaka, serta menyusunnya sesuai dengan template jurnal yang dituju untuk publikasi, baik pada jurnal lokal, nasional terdaftar, nasional terakreditasi, atau bahkan pada jurnal internasional bereputasi terindeks scopus. Untuk saat ini, 
kegiatan pendampingan ini, pelaksanaannya dibatasi pada guru-guru TK Yayasan Pondok Pesantren Darussholihin NW Kalijaga Kabupaten Lombok Timur.

Berdasarkan hasil studi awal melalui interaksi informal tim pengabdian dengan salah satu persolan pengelola pendidikan di Yayasan Pondok Pesantren Darussholihin NW Kalijaga Kabupaten Lombok Timur, didapatkan informasi bahwa para guru secara umum tidak memiliki karya ilmiah. Situasi ini dikarenakan para guru tidak memiliki pengetahuan yang cukup juga motivasi untuk menyusun karya ilmiah guna menunjang pengembangan keprofesian berkelanjuatan (PKB). Hasil pendahuluan ini menandakan bahwa bagi guru TK di Yayasan Pondok Pesantren Darussholihin NW Kalijaga Kabupaten Lombok Timur perlu dilakukan pelatihan penyusunan karya ilmiah.

Sesuai dengan paparan di atas, maka dalam kegiatan pengabdian ini dirumuskan tiga masalah sebagai berikut:

1. Bagaimanakah melatihkan para guru TK Yayasan Pondok Pesantren Darussholihin NW Kalijaga Kabupaten Lombok Timur dalam menyusun karya ilmiah berbasis Penelitian Tindakan Kelas (PTK) guna mewujudkan Pengembangan Keprofesian Berkelanjutan (PKB)?

2. Bagaimanakah respon para TK Yayasan Pondok Pesantren Darussholihin NW Kalijaga Kabupaten Lombok Timur terhadap upaya kegiatan pelatihan penyusunan karya ilmiah berbasis PTK guna menunjang PKB?

3. Bagaimanakah strategi pengembangan pelatihan penyusunan karya ilmiah bagi para guru TK Yayasan Pondok Pesantren Darussholihin NW Kalijaga Kabupaten Lombok Timur supaya efektif dan efisien?

Tujuan pengabdian pada masyarakat ini adalah:

1. Mengidentifikasi kondisi terkini kemampuan para guru TK Yayasan Pondok Pesantren Darussholihin NW Kalijaga Kabupaten Lombok Timur dalam menyusun karya ilmiah berbasis PTK,

2. Mengidentifikasi respon para guru TK Yayasan Pondok Pesantren Darussholihin NW Kalijaga Kabupaten Lombok Timur terhadap pelatihan penyusunan karya ilmiah sebagai penunjang PKB, dan
3. Menentukan strategi pelatihan penyusuna karya ilmiah bagi para guru TK di Yayasan Pondok Pesantren Darussholihin NW Kalijaga Kabupaten Lombok Timur yang efektif dan efisien dalam menunjang PKB.

\section{E. Manfaat Kegiatan}

Kegiatan pelatihan ini diharapkan dapat memberikan manfaat, bagi para guru TK di Yayasan Pondok Pesantren Darussholihin NW Kalijaga Kabupaten Lombok Timur, seperti:

1. Memiliki kesadaran dan motivasi untuk menyusun karya ilmiah berbasis PTK,

2. Memiliki pengetahuan tentang penyusunan karya ilmiah berbasis PTK,

3. Dapat merencanakan kegiatan penelitian tindakan kelas berbasis masalah yang dihadapi di kelas, dan

Memiliki kesadaran dan motivasi tentang perlunya mempublikasikan hasil penelitian melalui jurnal ilimiah, baik jurnal lokal, nasional, hingga jurnal.

\section{Metode}

\section{A. Tahapan Pemecahan Masalah}

Untuk memecahkan masalah di atas perlu diadakan pengabdian kepada para guru TK di Yayasan Pondok Pesantren Darussholihin NW Kalijaga Kabupaten Lombok Timur sebagai mitra tentang pengembangan karya ilmiah dan publikasinya. Dalan pengabdian ini diawali dengan analisis situasi calon partisipan kemudian dilanjutkan dengan kegiatan identifikasi penguasaan konsep Penelitian Tindakan Kelas (PTK), identifikasi strategi pelatihan, terutama jika masa pandemi Covid-19 ini belum selesai, pembekalan materi PTK dan penyusunan karya ilmiah, dan terakhir dilakukan evaluasi hasil kegiatan

Kerangka Pengabdian Penyusunan Karya Ilmiah: 1) Kondisi awal, Guru belum termotivasi untuk menyusun karya ilmiah; Kegiatan, Dilakukan sosialisasi tentang pentingnya pengembangan karya ilmiah bagi guru; Diharapkan, Partisipan memiliki pengetahuan pentingnya penyusunan karya ilmiah sebagai bagian dari pengembangan kualitas pendidikan. 2) Kondisi awal, Partisipan belum mampu merencanakan 
kegiatan PTK; Kegiatan, Paparan strategi melaksanakan PTK, Diharapkan, Partisipan dapat merencanakan dan melaksanakan PTK. 3) Kondisi awal, Partisipan belum pernah atau tidak terbiasa menyusun artikel untuk publikasi; Kegiatan, Dilatihkan strategi penulisan artikel dan cara mempublikasikannya; Diharapkan, Partisipan dapat merencanakan dan melaksanakan penulisan artikel, serta mempublikasikannya pada jurnal ilmiah.

\section{B. Khalayak Sasaran Antara Yang Strategis}

Kegiatan pengabdian pada masyarakat ini melibatkan semua guru TK di Yayasan Pondok Pesantren Darussholihin NW Kalijaga Kabupaten Lombok Timur sesuai keterjangkauan, terutama dikaitkan dengan pembatasan Protokol Kesehatan dalam situasi pandemi Covid-19 ini.

\section{Keterkaitan Kegiatan}

Dilematika kualitas pendidikan sudah semestinya tidak hanya dipikirkan oleh pihak lembaga pendidikan saja, tetapi menjadi permasalahan semua unsur yang terkait, seperti PEMDA setempat, pihak sekolah, dan perguruan tinggi sebagai penghasil tenaga pendidik maupun kependidikan. Kualitas pendidikan TK juga dapat ditingkatkan melalui kegiatan pengabdian pendidikan dan publikasi ilmiah pada jurnal lokal, nasional belum terakreditasi, nasional terakreditasi, dan/atau jurnal internasional, serta sosialisasi secara langsung terhadap subjek sasaran, dalam hal ini para guru TK di Yayasan Pondok Pesantren Darussholihin NW Kalijaga Kabupaten Lombok Timur. Selanjutnya, kegiatan pengabdian ini juga bermanfaat lembaga pendidikan untuk membangkitkan gagasannya dalam Pengembangan Keprofesian Berkelanjutan (PKB) untuk memulai melakukan kegiatan pengabdian, khususnya penyusunan karya ilmiah. Suasana kerjasama secara melembaga juga perlu diwujudkan dengan jangkauan sasaran yang lebih luas. Melalui pengabdian ini, diharapkan pula terjalin kerjasama yang semakin baik antara Pascasarjana Universitas Mataram dengan Penyelenggara pendidikan pada jenjang Taman Kanak-kanak, lembaga TK di Yayasan Pondok Pesantren Darussholihin NW Kalijaga Kabupaten Lombok Timur.

\section{Metode Kegiatan}

Pengabdian ini menggunakan metode ceramah, tanya-jawab, dan peragaan tentang perencanaan PTK, pengembangan instrumen, dan penulisan artikel untuk publikasi.

\section{E. Evaluasi}

Evaluasi ditujukan untuk memanfaatkan informasi yang diperoleh sebagai acuan dalam menentukan kegiatan selanjutnya. Evaluasi ini direncanakan dilakukan pada bagian proses pelaksanaan dan bagian akhir kegiatan dengan cara mengidentifikasi respon partisipan, serta efektivitas dan efisiensinya kegiatan pengabdian ini. Evaluasi tentang respon guru dijaring menggunakan openended question sehingga selain diperoleh informasi yang sudah diarahkan juga didapatkan pendapat partisipan dalam sudut pandang yang lebih terbuka.

\section{Hasil dan Pembahasan}

Hasil Kegiatan: Pembahasan difokuskan pada respon para peserta pengabdian yang berjumlah 45 orang guru (tujuh di ataranya merangkap sebagai kepala sekolah) tersebar di 11 Madrasyah Ibtidaiyah (MI) dan 34 Taman Kanakkanak (TK) yang berada di bawah naungan Yayasan Pondok Pesantren Darussolihin Nahdatul Wathon, Kabupaten Lombok Timur, Provinsi Nusa Tenggara Barat (Lampiran 1). Respon para peserta dijaring menggunakan angket yang mencakup 11 pertanyaan berkenaan dengan upaya Pengembangan Keprofesian Berkelanjutan (PKB), khususnya yang berkaitan dengan penulisan karya ilmiah melalui Penelitian Tindakan Kelas (PTK) atau melalui kajian pustaka.

Dalam kegiatan pengabdian berkenaan dengan pelatihan penulisan karya ilmiah dilakukan urutan kegiatan dari pemaparan tentang sejauh mana publikasi ilmiah itu penting bagi para guru, kerangka konseptual karya ilmiah, jenis karya ilmiah yang berpotensi dikembangakan guru, serta pemaparan kerangka konseptual Penelitian Tindakan Kelas (PTK). Pada bagian akhir kegiatan melalui zoom dilakuan diskusi dan tanya jawab seputar penyusunan sebuah karya ilmiah, khususnya artikel ilmiah hasil PTK, hingga proses mempublikasikannya.

Setelah selesai kegiatan pengabdian melalui zoom, peserta diminta mengisi google form untuk mendapatkan data profil para guru di lingkungan 
Yayasan Pondok Pesantren Darussolihin NW di Kabupaten Lombok Timur - NTB dalam hal Pengembangan Keprofesian Berkelanjutan (PKB) melalui jalur publikasi ilmiah. Hasil analisis angket yang dihimpun menggunakan google form, didapat data profil peserta pengabdian sebagaimana diperlihatkan dalam Tabel 4.1 hingga Tabel 4.9

Tabel 4.1 Data Kepemilikan Publikasi Ilmiah bagi Peserta Pengabdian

\begin{tabular}{|l|l|r|}
\hline No. & \multicolumn{1}{|c|}{ Uraian } & Persentase \\
\hline 1 & $\begin{array}{l}\text { Peserta yang sudah memiliki } \\
\text { publikasi ilmiah }\end{array}$ & 15,56 \\
\hline 2 & $\begin{array}{l}\text { Peserta yang belum memiliki } \\
\text { publikasi ilmiah }\end{array}$ & 84,44 \\
\hline
\end{tabular}

Tabel 4.2 Data Jenis Publikasi Ilmiah Yang Sudah Dimiliki Peserta Pengabdian

\begin{tabular}{|l|l|r|}
\hline No. & \multicolumn{1}{|c|}{ Uraian } & Persentase \\
\hline 1 & Jurnal lokal & 0 \\
\hline 2 & Jurnal nasional & 14,29 \\
\hline 3 & Jurnal nasional terakreditasi & 0 \\
\hline 4 & Jurnal internasional & 0 \\
\hline 5 & Buku ajar & 14,29 \\
\hline 6 & Buku teks & 0 \\
\hline 7 & $\begin{array}{l}\text { Jenis lainnya (laporan } \\
\text { penelitian, laporan pengabdian) }\end{array}$ & 71,42 \\
\hline
\end{tabular}

Tabel 4.3 Tahun Publikasi Ilmiah Peserta Pengabdian

\begin{tabular}{|l|l|r|}
\hline No. & \multicolumn{1}{|c|}{ Uraian } & Persentase \\
\hline 1 & Tiga tahun terakhir & 28,57 \\
\hline 2 & Lebih dari tiga tahun yang lalu & 57,14 \\
\hline
\end{tabular}

Catatan: Satu peserta tidak mengkonfirmasi tahun terbitnya

Tabel 4.4 Kondisi Kebutuhan Publikasi Ilmiah Peserta Pengabdian

\begin{tabular}{|l|l|r|}
\hline No. & \multicolumn{1}{|c|}{ Uraian } & Persentase \\
\hline 1 & $\begin{array}{l}\text { Sudah memerlukan publikasi } \\
\text { ilmiah }\end{array}$ & 78,57 \\
\hline 2 & $\begin{array}{l}\text { Belum memerlukan publikasi } \\
\text { ilmiah }\end{array}$ & 21,43 \\
\hline
\end{tabular}

Catatan: Sepuluh dari 13 yang belum memerlukan publikasi tidak memiliki alasan tertentu, sisanya tidak ada konfirmasi.

Tabel 4.5 Kendala dan Kondisi Peserta Pengabdian dalam Menyusun Karya Ilmiah

\begin{tabular}{|l|l|r|}
\hline No. & \multicolumn{1}{|c|}{ Uraian } & Persentase \\
\hline 1 & $\begin{array}{l}\text { Tidak memiliki waktu untuk } \\
\text { menulis }\end{array}$ & 3,03 \\
\hline 2 & Berkeinginan menulis tetapi & 72,73 \\
\hline
\end{tabular}

\begin{tabular}{|l|l|r|}
\hline & mengalami kesulitan & \\
\hline 3 & Kendala lain & 9,09 \\
\hline
\end{tabular}

Tabel 4.6 Data Kesediaan Peserta Pengabdian untuk Dibantu Menyusun Karya Ilmiah

\begin{tabular}{|l|l|r|}
\hline No. & \multicolumn{1}{|c|}{ Uraian } & Persentase \\
\hline 1 & Bersedia & 93,33 \\
\hline 2 & Tidak bersedia & 6,67 \\
\hline
\end{tabular}

Catatan: Untuk yang tidak bersedia, $30 \%$ menyatakan menunggu difasilitasi oleh sekolah sedangkan sisanya tidak memiliki alasan tertentu.

Tabel 4.7 Data Kesediaan Frekuensi Bimbingan Penyusunan Karya Ilmiah

\begin{tabular}{|l|l|r|}
\hline No. & \multicolumn{1}{|c|}{ Uraian } & Persentase \\
\hline 1 & Seminggu sekali & 4,76 \\
\hline 2 & Dua minggu sekali & 9,52 \\
\hline 3 & $\begin{array}{l}\text { Dengan frekuensi sesuai } \\
\text { kebutuhan }\end{array}$ & 85,71 \\
\hline
\end{tabular}

Tabel 4.8 Data Jenis Bimbingan Penyusunan Karya Ilmiah Yang Diminta

\begin{tabular}{|l|l|r|}
\hline No. & \multicolumn{1}{|c|}{ Uraian } & Persentase \\
\hline 1 & Menyusun proposal PTK & 24,44 \\
\hline 2 & Menyusun instrumen PTK & 8,89 \\
\hline 3 & Melaksanakan PTK & 20,00 \\
\hline 4 & Menyusun laporan PTK & 33,33 \\
\hline 5 & Menyusun artikel hasil PTK & 8,89 \\
\hline 6 & $\begin{array}{l}\text { Menyusun artikel hasil kajian } \\
\text { pustaka }\end{array}$ & 4,44 \\
\hline
\end{tabular}

Tabel 4.9 Saran Saran/Komentar Bapak/Ibu Berkenaan Dengan Penyusunan Karya Ilmiah Guru

\begin{tabular}{|l|l|}
\hline No. & \multicolumn{1}{|c|}{ Saran / Komentar } \\
\hline 1 & $\begin{array}{l}\text { Menulis karya ilmiah itu sangat penting oleh } \\
\text { karena itu kami perlu bimbingannn bapk }\end{array}$ \\
\hline 2 & Mohon untuk bimbingannyq \\
\hline 3 & Mohon bimbingannya \\
\hline 4 & $\begin{array}{l}\text { Penulisan karya ilmiyah sangat besar manfaatnya } \\
\text { bagi guru.untuk membuka wawasan yang selus } \\
\text { luasnya bagi guru itu sendiri. }\end{array}$ \\
\hline 5 & $\begin{array}{l}\text { Belum pernah membuat karya ilmiah selama } \\
\text { masa jabatan }\end{array}$ \\
\hline 6 & Butuh bimbingan \\
\hline 7 & Butuh bimbingan \\
\hline 8 & Butuh bimbingan \\
\hline 9 & $\begin{array}{l}\text { Langsung pembuatan mulai dari tahap awal } \\
\text { sampai selesai }\end{array}$ \\
\hline 10 & $\begin{array}{l}\text { Karya ilmiah sngat penting...kami sbga guru perlu } \\
\text { bimbingan }\end{array}$ \\
\hline
\end{tabular}




\begin{tabular}{|c|c|}
\hline 11 & $\begin{array}{l}\text { Sangat baik sekali kalau ibu guru bisa menyusun } \\
\text { karya ilmiah, karna bisa mengembangkan } \\
\text { wawasan atau pemikirannya sehingga semakin } \\
\text { bertambah pengetahuan yg dimilikinya }\end{array}$ \\
\hline 12 & $\begin{array}{l}\text { Enak Bisa menyampaikan ilmu pengetahuan sbg } \\
\text { sarana penyampaian inpormasi }\end{array}$ \\
\hline 13 & Tolong kami di bombing \\
\hline 14 & $\begin{array}{l}\text { Dalam penyusunan karya ilmiah guru, saya } \\
\text { kesulitan dari segi teori dan materi sehingga saya } \\
\text { menyarankan untuk sekolah saya untuk } \\
\text { mempermudah dan memfasilitasi saya dari } \\
\text { kesulitan tersebut. }\end{array}$ \\
\hline 15 & Supaya bisa menjadi guru yg lebih baik \\
\hline 16 & $\begin{array}{l}\text { Sangat penting untuk meningkatkan pengetahuan } \\
\text { guru dalam pembelajaran }\end{array}$ \\
\hline 17 & Supaya bisa jadi guru yg lebih baik \\
\hline 18 & $\begin{array}{l}\text { Sangat membutuhkan karya ilmiah itu sangat } \\
\text { baik. }\end{array}$ \\
\hline 19 & $\begin{array}{l}\text { Sangat penting untuk meningkatkan kemajuan } \\
\text { sekolah. }\end{array}$ \\
\hline 20 & $\begin{array}{l}\text { Untuk meningkatkan kemajuan sekolah dan } \\
\text { pengetahuan guru. }\end{array}$ \\
\hline 21 & $\begin{array}{l}\text { Saran saya penting untuk membuat karya ilmiah } \\
\text { untuk menigkatkan mutu pembelajaran guru }\end{array}$ \\
\hline 22 & $\begin{array}{l}\text { Kami sangat } 2 \text { membutuhkan bimbingan langsung } \\
\text { untuk menulis PTK. }\end{array}$ \\
\hline 23 & Untuk bisa menjadi guru yg lebih baik \\
\hline 24 & $\begin{array}{l}\text { Keterbatasan sekolah kami dari segi teori dan } \\
\text { materi membuat penyusunan karya ilmiah guru } \\
\text { akan Mengalami kendala }\end{array}$ \\
\hline 25 & $\begin{array}{l}\text { Semoga dgn adanya pelatihan ini kami bisa } \\
\text { menyusun hasil dari observasi dari anak didik } \\
\text { kami nantinya }\end{array}$ \\
\hline 26 & Semoga segera dilaksanakan \\
\hline 27 & $\begin{array}{l}\text { Segra dilaksanakan tatap muka, untuk lebih } \\
\text { paham }\end{array}$ \\
\hline 28 & Mohon bimbingan \\
\hline 29 & $\begin{array}{l}\text { Terimakasih atas ketersediaan nya untuk } \\
\text { membantu membuat publikasi ilmiah }\end{array}$ \\
\hline 30 & Butuh bimbingan yang maksimal \\
\hline 31 & $\begin{array}{l}\text { Laporan PTK bisa di lakuakn oleh setiao guru. } \\
\text { Minimal 1x dalam posisinya menjadi gurKarena } \\
\text { dengan pertimbangan pentingnya manfaat dari } \\
\text { karya ilmiah bagi guru, sekolah dan siswanya. } \\
\text { Sehingga guru bisa meng Up Date segala bentuk } \\
\text { strategi pembwlajran, dan solusi } \hat{A}^{2} \text { dari berapa } \\
\text { permsalahan kecil pendidikan di sekolah. }\end{array}$ \\
\hline 32 & $\begin{array}{l}\text { Dalam menyusun karya ilmiah bisakah dijelaskan } \\
\text { dgn jelas baik melalui audio ataupun audio visual }\end{array}$ \\
\hline 33 & $\begin{array}{l}\text { Sangat setuju,karena dapat memperluas wawasan } \\
\text { dalam membaca maupun menulis }\end{array}$ \\
\hline 34 & $\begin{array}{l}\text { Terima kasih sudah bersedia memberikan } \\
\text { bimbingan }\end{array}$ \\
\hline 35 & Butuh bimbingan \\
\hline 36 & Penyusunan karya ilmiah guru sangat baik untuk \\
\hline
\end{tabular}

\begin{tabular}{|l|l|}
\hline & $\begin{array}{l}\text { meningkatkan kualitas dari seorang guru dan } \\
\text { tenaga pendidik, kami sangat mengharapkan } \\
\text { bimbingan dari bapak/ibu. Terimakasih }\end{array}$ \\
\hline 37 & Mohon bimbingan \\
\hline 38 & Mohon bimbingannya \\
\hline 39 & mohon bimbingan \\
\hline 40 & Moron bimbingan \\
\hline 41 & Mohon bimbingannya \\
\hline 42 & Butuh nimbingan \\
\hline 43 & $\begin{array}{l}\text { Program yang sangat bagus sekali untuk } \\
\text { menambah ilmu pengetahuan kami }\end{array}$ \\
\hline 44 & $\begin{array}{l}\text { kegiatan yang bagus sekalu untuk menambah } \\
\text { ilmu pengetahuan kami }\end{array}$ \\
\hline 45 & $\begin{array}{l}\text { Publikasi itu sangat mendukung sekali karena } \\
\text { dapat menambah ilmu pengetahuan kami }\end{array}$ \\
\hline
\end{tabular}

Pembahasan: Kehadiran tim pengabdian dalam upaya membantu para guru Madrasyah Ibtidaiyah (MI) (34 guru) dan Taman Kanak-kanak (TK) (11 guru) di naungan Yayasan Pondok Pesantren Darussolihin Nahdatul Wathon (NW) Kabupaten Lombok Timur, Provinsi Nusa Tenggara Barat (NTB), Indonesia, mendapat sambutan sangat baik. Hal ini antara lain ditunjukkan sikap antusias dan keseriusan para guru untuk mengikuti seluruh rangkaian kegiatan pengabdian ini hingga tahap akhir, yaitu pengisian angket menggunakan fasilitas google form. Hasil pengisian angket juga memperlihatkan kesungguhan para peserta pengabdian yang antara lain diperlihatkan dengan kuantitas jawaban, yaitu hampir seluruh peserta memberi respon atau jawaban pertanyaan dalam angket tersebut.

Selanjutnya, hasil analisis diperoleh data $84,44 \%$ guru belum memiliki publikasi ilmiah, sisanya $15,56 \%$ sudah memiliki publikasi ilmiah (Tabel 4.1). Jenis publikasi yang sudah dimiliki guru terdiri atas jurnal nasional (14,29\%), buku ajar $(14,29 \%)$, dan jenis lainnya seperti laporan penelitian dan laporan pengabdian $(71,42 \%)$ (Tabel 4.2) dengan massa terbit tiga tahun terakhir $(28,57 \%)$, lebih dari tiga tahun yang lalu $(57,14 \%)$, dan sisanya (satu peserta) tidak mengkonfirmasi tahun terbitnya (Tabel 4.3).

Meskipun ada $84,44 \%$ guru yang belum memiliki publikasi ilmiah, namun sebenarnya secara umum para guru sudah memerlukan publikasi ilmiah tersebut. Hasil analisis terdapat $78,57 \%$ guru yang sudah memerlukan publikasi ilmiah tetapi saat ini belum memilikinya. Sisanya hanya $21,43 \%$ (13 guru) yang merasa belum memerpukan publikasi ilmiah. Dari 13 guru 
tersebut, sepuluh orang tidak memiliki alasan tertentu mengapa belum memerlukan publikasi ilmiah sedangkan sisanya, tiga orang guru, tidak memberi konfirmasi (Tabel 4.4).

Selanjutnya, secara umum kendala bagi guru peserta pengabdian yang menjadi penyebab belum memiliki publikasi ilmiah adalah mereka mengalami kesulitan meskipun sebenarnya berkeinginan untuk menulis $(72,73 \%)$. Sisanya $3,03 \%$ guru menyatakan tidak memiliki waktu untuk menulis dan $9,09 \%$ menyatakan adanya kendala jenis lainnya (Tabel 4.5).

Pada saat kegiatan pengabdian, tim pengabdian menyampaikan bahwa kami bersepakat siap membantu para guru dalam menghasilkan karya ilmiah. Selanjutnya kepada para peserta pengabdian, seiring dengan potensi bantuan ini ditawarkan apakah bersedia dibantu oleh tim pengabdian, hasilnya memperlihatkan bahwa hampir semua $(93,33 \%)$ menyatakan bersedia. Sisanya $6,67 \%$ menyatakan tidak bersedia dengan alasan mereka menunggu difasilitasi oleh sekolah (Tabel 4.6).

Bagi guru yang bersedia dibantu menghasilkan karya ilmiah menyatakan perlunya dilakukan pembimbingan dengan frekuensi seminggu sekali $(4,76 \%)$, dua kali seminggu $(9,52 \%)$, dan dengan frekuensi sesuai kebutuhan sebanyak 85,71\% (Tabel 4.8). Selanjutnya, ketika kepada para guru ditanyakan jenis bimbingan yang diperlukan, dari enam jenis bimbingan yang ditawarkan diperoleh informasi guru yang memerpukan bimbingan penyusunan proposal Penelitian Tindakan Kelas (PTK) sebanyak 24,44\%; penyusunan instrumen PTK sebanyak 8,89\%; pelaksanaan PTK sebanyak 20,00\%; penyusunan laporan PTK sebanyak 33,33\%; penyusunan artikel hasil PTK sebanyak $8,89 \%$; dan penyusunan artikel hasil kajian pustaka sebanyak $4,44 \%$. Dengan demikian, jenis bimbingan publikasi karya ilmiah untuk para guru di lingkungan yayasan pondok pesantren tersebut terutama pada tiga kegiatan, yaitu penyusunan proposal PTK, pelaksanaan PTK, dan penyusunan laporan PTK (Tabel 4.8).

Selanjutnya melalui isian saran atau komentar secara terbuka dipeoleh data bahwa pada dasarnya para guru di Yayasan Pondok Pesantren Darussolihin NW sangat memerlukan bimbingan untuk menghasilkan karya ilmiah dan sekaligus mempublikasikannya. Dari paparan bebas tersebut tercermin adanya keinginan yang sangat kuat bari para guru di yayasan tersebut untuk mendapat kegiatan pembimbingan publikasi karya ilmiah sebagai kegiatan lanjutan pengabdian ini (Tabel 4.9).

\section{Kesimpulan}

Kegiatan pengabdian kepada masyarakat berkelanjutan bagi guru-guru Madrasah Ibtidaiyah (MI) dan Taman Kanak-kanak (TK) di lingkungan Yayasan Pondok Pesantren Darussolihin NW, Kabupaten Lombok Timur, NTB telah dilakukan dengan kemasan berbentuk kegiatan pemaparan kerangka konseptual karya ilmiah hingga penjaringan potensi kegiatan pendampingan pengembangan karya ilmiah. Kegiatan ini diikuti 45 guru yayasan yang tersebar 11 guru TK dan 34 guru MI dan semuanya memberi respon sangat positif terhadap kegiatan ini. Respon positif tersebut antara lain diperlihatkan oleh para guru yaitu adanya motivasi yang tinggi untuk mendapatkan pembimbingan lanjutan untuk menghasilkan karya ilmiah. Pembimbingan yang cenderung diminta ada tiga, yaitu penyusunan dan pelaksanaan PTK, serta pembuatan laporannya.

\section{Saran}

Selanjutnya, berdasarkan hasil analisis data angket disarankan agar dilakukan kegiatan lanjutan yaitu pada kegiatan pengabdian kepada masyarakat tahun berikutnya. Kegiatannya disarankan secara operasional dilatihkan teknik pengembangan karya ilmiah, menyusun laporan dan artikel hingga proses mempublikasikannya.

\section{Ucapan Terima Kasih}

Penulis mengucapkan terima kasih kepada Kementerian Pendidikan, Kebudayaan, ristek dan Pendidikan Tinggi, yang melalui Pascasarjana Universitas Mataram dan Lembaga Penelitian dan Pengabdian Masyarakat (LPPM) telah memberi dukungan financial terhadap pengabdian ini. Ucapan terima kasih juta disampaikan kepada para guru MI dan TK di Yayasan Pondok Pesantren Darussolihin NW Kalijaga Lotim, NTB yang telah berpartisipasi sebagai peserta dalam kegiatan pengabdian ini. 


\section{Daftar Pustaka}

Bordens, K., S., and Abbott, B., B., 2014. Research Design and Methods, A Process Approach, ninth edition. New York: McGraw-Hill Education

Creswell, J. W., 2008. Educational Research, planning, conducting, and evaluating quantitative and qualitative research. USA: Pearson Prentice Hall

Nasir, Muhamad. 2015. Peraturan Menteri Riset, Teknologi, dan Pendidikan Tinggi Republik Indonesia Nomor 44 Tahun 2015 tentang Standar Nasional Pendidikan Tinggi. Jakarta: Dirjen Peraturan Perundang-undangan Kemenhum dan Hak Asasi Manusia Republik Indonesia.

Nuh, M., 2010. Petunjuk Teknis Pelaksanaan Jabatan Fungsional Gurudan Angka Kreditnya, Permendiknas no 35. Diknas RI, Kabiro Hukum dan Organisasi

Riduwan, 2013. Skala Pengukuran Variabelvariabel Penelitian. Bandung: Penerbit Alfabeta 